\title{
Studies on Green Fodder Yield, Quality and Economics of Cereal Forage Sown alone and Intercrop with Cowpea
}

\author{
Ramanand Chaudhary ${ }^{1}$, Sanjeev Kumar Gupta ${ }^{1^{*}}$, Anshuman Kohli ${ }^{2}$, \\ Suborna Roy Choudhury ${ }^{1}$ and M. K. Singh ${ }^{1}$ \\ ${ }^{1}$ Department of Agronomy and ${ }^{2}$ Department of Soil Science and Agricultural Chemistry, Bihar \\ Agricultural College, Sabour, Bhagalpur, Bihar, India \\ *Corresponding author
}

\section{A B S T R A C T}

Field experiment was conducted at research farm Bihar agricultural university, Sabour during Kharif -2019 to find the appropriate row ratio of cereal and legume intercrop for better quality of forage with maximum net returns. Intercropping system had significant

\section{Keywords}

Intercropping, Weighted average crude protein, Crude protein yield, Crude fiber, Net return and Benefit cost ratio

\section{Article Info}

Accepted: 12 October 2020 Available Online: 10 November 2020 effect on nutritive value of forage crops and economics. The experiment was laid out in randomized block design consisting of 11 treatments $e$. $i$. sole sorghum, sole pearl millet, sole cowpea, sorghum + cowpea and pearl millet + cowpea intercropping each with 1:1, $1: 2,2: 1,2: 2$ row ratio with three replications. Among the different row ratios of intercropping, the green fodder and dry fodder yield as 491.0 and $103.30 \mathrm{q} \mathrm{ha}^{-1}$ respectively were found significantly higher with 2:1 row ratio intercropping of sorghum and cowpea. Quality parameters of cereal fodder were influenced by intercropping of cowpea because it is able to fix the atmospheric $\mathrm{N}$, some part of which might have become available to cereal crop. In aspect of quality parameter the average crude protein $(18.16 \%)$ and ash content $(15.89 \%)$ were found significantly higher with minimum average crude fiber content $(23.42 \%)$ in sole cowpea followed by 1:2 row ratio intercropping of pearl millet + cowpea and sorghum + cowpea. Whereas, crude protein yield $\left(5.52 \mathrm{q} \mathrm{ha}^{-1}\right)$ was found significantly higher with 2:1 row ratio intercropping of sorghum and cowpea due to its greater biomass production followed by 1:1 and 2:2 row ratio of sorghum and cowpea. The Highest gross return $\left(79,731 \mathrm{Rs} \mathrm{ha}^{-1}\right)$, net returns $\left(55,597 \mathrm{Rs} \mathrm{ha}^{-1}\right)$ and $\mathrm{B}$ : C ratio (2.30) was obtained under 2:1 row ratio intercropping of sorghum and cowpea which is significantly higher than all other treatments. Therefore it is concluded that, intercropping of sorghum and cowpea with 2:1 row ratio is found economically viable for farmers with quality green fodder and higher net returns.

\section{Introduction}

India's livestock sector is one of the largest in the world; livestock population is around 536.76 million in the country showing an increase of $4.8 \%$ over livestock census 2012
( $20^{\text {th }}$ Livestock census-2019 all India report). At the current level of growth in forage resources, there will be $18.4 \%$ deficit in green fodder and $13.2 \%$ deficit in dry fodder in the year 2050. Only large farmers $(<5 \%)$ grow any fodder, small and a marginal farmer $(90$ 
$\%$ ) depends on crop residues for feeding the livestock. Forages are considered to be the most palatable, economical and nutritious animal feed resource for livestock particularly for dairy animals (Ibrahim et al., 2012 and Iqbal, 2015). Intercropping of legumes and cereal is an old practice in tropical agriculture that dates back to ancient civilization. The main objective of intercropping has been to maximize use of resources such as space, light and nutrients (Li et al., 2003) as well as to improve crop quality and quantity (Mpairwe et al., 2002). The current trend in global agriculture is to search for highly productive, sustainable and environmental friendly cropping systems (Crew and Peoples, 2004). Cereal forages like sorghum can provide abundant quantities of green forage during summer months, but dairy animals fed on forage sorghum need protein and energy rich concentrates to make up for protein deficiency (Iqbal et al., 2015). Sorghumcowpea intercropping has been reported as one of the biologically and economically feasible options to increase the productivity and quality of forage (Rao et al., 2005; Ghosh et al., 2006). Cowpea is a rich source of plant protein and its inclusion in animal's feed reduces the need to supplement lactating animals with concentrates. Cowpea, being a leguminous crop, has the ability to fulfil a greater proportion of nitrogen requirement through nitrogen fixation process taking place in root nodules with the help of soil bacteria, namely, Rhizobium leguminasorum (Acikgoz et al., 2008). Fixed nitrogen not only improves vegetative growth of cowpea but also gets transferred to cereal crops through roots intermingling in cowpea based intercropping systems (Sheaffer et al., 2001).

The maximum fresh weight per plant, total green fodder yield, dry matter percentage and protein content were produced when sorghum was grown in mixture with cowpea (Abbas, 2005). Intercropping including legumes is known to enhance forage crude protein concentration compared with cereal sole cropping and to use resources more efficiently (Papastylianou, 2004). Abd El-Shafy et al., (2009) concluded that forage mixture were of more crude protein (CP) content than sole maize but less than cowpea in its pure stand, while crude fiber $(\mathrm{CF})$ content was less than sole maize and more than cowpea in its pure stand. Dahmardeh et al., (2010) concluded that intercropping of maize and cowpea resulted in more digestible dry matter and also crude protein content than maize sole cropping. Javanmard et al., (2009) worked on intercropping of maize with different legumes and indicated that, dry matter yield and crude protein yield of forage increased by all intercropping compositions as compared with maize monoculture. Due to rapid increase in population and reduction in cultivated area, horizontal increase in forage production is almost impossible; the possible approach is to increase its yield per unit area. Non-legume intercropped with legume significantly increased the total mixed green forage yield and crude protein content of mixed forage (Iqbal et al., 2006). In general, beneficial effects of legumes intercropped in cereals like- sorghum, maize have been observed under low fertility condition because legumes fix atmospheric nitrogen besides meeting their own $\mathrm{N}$ requirements. This eventually helps in meeting the $\mathrm{N}$ needs of cereals partially (Ibrar et al., 2002).

\section{Materials and Methods}

Field experiment was conducted at research farm Bihar agricultural university, sabour during Kharif season- 2019. It is located at $25^{\circ} 23^{\prime} \mathrm{N}, 78^{\circ} 07^{\prime} \mathrm{E}$ and 37.19 meters above the mean sea level. The soil of the experimental field was loamy in nature with medium in organic carbon, low in available nitrogen, available phosphorus and available potassium with almost neutral $\mathrm{pH}$ in reaction. 
The experiment was laid out in randomized block design (RBD) consisting of 11 treatments (sole sorghum, sole pearl millet, sole cowpea, sorghum + cowpea and pearl millet + cowpea intercropping each with $1: 1$, $1: 2, \quad 2: 1, \quad 2: 2$ row ratio). It has three replications and a net plot size is $6 \mathrm{~m} \times 3.6 \mathrm{~m}$ with 12 rows in each plot. Field was cultivated with cultivator 3 to 4 times and then planking was done to make the soil feasible for sowing. The seed rate of sorghum, pearl millet and cowpea was applied at the rate 18,08 and $30 \mathrm{~kg} \mathrm{ha}^{-1}$ respectively. The variety of sorghum, pearl millet and cowpea was used SSG 998, Gaint bajra and Bundel lobia-1 respectively. The recommended application of fertilizers $\left(\mathrm{N}, \mathrm{P}_{2} \mathrm{O}_{5}\right.$ and $\left.\mathrm{K}_{2} \mathrm{O}\right)$ was applied at the rate 80,60 and $40 \mathrm{~kg} \mathrm{ha}^{-1}$ for sole sorghum and pearl millet whereas, 20 , 60 and $40 \mathrm{~kg} \mathrm{ha}^{-1}$ for sole legumes but in intercropping system $40 \mathrm{~kg} \mathrm{~N}$ was applied in 1:1 and 2:2 row ratio while 40 and $60 \mathrm{~kg} \mathrm{~N}$ was applied in $1: 2$ and 2:1 row ratio respectively whereas, the dose of phosphorus and potash was same. In sole sorghum and pearl millet, $2 / 3^{\text {rd }}$ nitrogen along with all phosphorus and potash were applied as basal and the remaining $1 / 3^{\text {rd }}$ nitrogen was top dressed at 30 days after sowing (DAS) but in case of cowpea, whole nitrogen along with phosphorus and potash was applied as basal as well as per treatments. The source of nitrogen, phosphorus and potash were urea and di- ammonium phosphate (DAP) and murate of potash (MOP). Sole and intercrops were sown on 04 August, 2019 and harvested at 55 to 60 days after sowing as per $50 \%$ flowering stage of individual crop. In recording the green fodder yield from net plot area were harvested separately from ground surface and weighed. Green fodder yield of sorghum, pearl millet and cowpea were weighed separately and total green fodder was expressed in $\mathrm{q} \mathrm{ha}^{-1}$. Dry fodder was recorded at harvest stage separately for sorghum, pearl millet and cowpea. The green fodder from the net plot area was dried in sun on the threshing floor till 20-25\% moisture level and the dry fodder yield was recorded and expressed in $\mathrm{q}$ ha $^{-1}$.

The collected plant samples from each treatment were sun dried and further oven dried at $65 \pm 5^{\circ} \mathrm{C}$. The oven dried samples were ground in a Willy grinding mill and used for analysis of quality parameters as recommended by Association of Official Agriculture Chemist (A.O.A.C., 1990). The crude protein content of plant was estimated by multiplying with factor 6.25 to the nitrogen percentage. Crude protein yield was calculated by multiplying crude protein per cent with dry matter accumulation of respective treatment. The weighted average of crude protein (WACP) was calculated by the crude protein yield and dry matter accumulation. The sorghum equivalents yield, land equivalent ratio and $\mathrm{B}$ : $\mathrm{C}$ ratios were calculated by applying standard methods to compare the benefits of intercropping systems.

\section{Results and Discussion}

The results obtained from the present investigation as well as relevant discussion have been summarized under following details.

\section{Green fodder and dry fodder yield}

Data presented in table- 1 indicates the green fodder and dry fodder yield of sorghum, pearl millet and cowpea were affected by intercropping pattern. The maximum total green fodder and dry fodder yield (sorghum, pearl millet and cowpea) was obtained from the sorghum and cowpea with 2:1 row ratio i.e. $490.99 \mathrm{q} \mathrm{ha}^{-1}$ and $103.3 \mathrm{q} \mathrm{ha}^{-1}$ respectively, while sole sorghum having $460.83 \mathrm{q} \mathrm{ha}^{-1}$ of green biomass and $100.81 \mathrm{q}$ $\mathrm{ha}^{-1}$ dry biomass which is statistically at par with intercropping of sorghum and cowpea 
with 2:1 row ratio. This result indicates the complementary and non competitive effects of these intercrops due to differences in the temporal and spatial characteristics of the crops Girase et al., (2007). The improved performance of the intercropping system was attributed to better utilization of resources, particularly soil moisture and nutrients (Gare et al., 2009). Similar result was found by Sapna et al., (2017) they were stated that among the intercropping treatments, intercropping of maize with cowpea in 2:1 row ratio significantly the highest green fodder biomass and yield. Same result was also reported by sorghum-cowpea and Sorghum-cluster bean intercropping in a 2:1 row proportion resulted in the highest fresh and dry biomass than other spatial arrangements (Iqbal et al., 2018).

\section{Sorghum Equivalent Yield (SEY)}

The data of SEY is also presented in table 1 shows the effect of intercropping on sorghum equivalent yield. Among the all treatments sorghum and cowpea intercropping 2:1 row ratio having maximum sorghum equivalent yield followed by $1: 1$ and 2:2 row ratio of sorghum and cowpea intercropping. The higher fodder price of cowpea than sorghum, pearl millet and higher green biomass production might be a factor for improving sorghum equivalent yield. This result is in conformity with the finding of Pal et al., (2014) reported higher sorghum equivalent yield in sorghum + cowpea and sorghum + ricebean intercropping system and Amedie et al., (2004) also reported higher sorghum equivalent yield in sorghum + French bean intercropping system followed by sorghum + soybean intercropping system.

\section{Land equivalent ratio (LER)}

Sorghum and cowpea 2:1 row ratio having maximum LER followed by 1:1 and 2:2 sorghum and cowpea intercropping. The higher LER is attributed to higher green fodder yield of both crops under intercropping systems (Table-1). This result was in conformity with the finding of Pal et al., (2014) who reported maximum land equivalent ratio (LER) in sorghum + cowpea intercropping system. Similar result was also found by Oseni et al., (2010) and reported that an intercropping of sorghum and cowpea under different row ratio showed that 2:1 row ratio gave a better land equivalent ratio (LER) as compared to other planting patterns.

\section{Quality parameters}

\section{Weighted average of crude protein, crude fiber and ash content}

\section{Crude protein content}

Data pertaining to average crude protein content are presented in the table 2. The maximum crude protein was found in sole cowpea $(18.16 \%)$ followed by intercropping of pearl millet + cowpea in $1: 2$ row ratio $(12.61 \%)$ and sorghum + cowpea in 1:2 row ratio $(12.37 \%)$ which is statistically at par with each other and significantly greater than other treatments except sole cowpea. The improvement in quality of cereal fodder under intercropping system might possibly the result of fixation of nitrogen either by direct excretion from the leguminous nodule root system or by decomposition of nodules and root debris.

These findings are conformed to the result obtained by Singh et al., (1983). The legume intercrops were able to grow better, fixing greater amount of atmospheric $\mathrm{N}$, some part of which might have become available to cereal crop. This might be the possible reason for obtaining higher crude protein content of cereal fodder in intercropping system. These finding was also obtained by Eskandari and Ghanbari (2009). 


\section{Crude fibre}

Data pertaining to average crude fiber content are also presented in the table 2. The maximum crude fiber content was found in sole sorghum $(29.21 \%)$ which was significantly higher than all other treatments and followed by sole pearl millet $(29.11 \%)$. The minimum crude fiber was noticed in sole cowpea $(23.42 \%)$. All plants are composed of cells having fibrous cell walls for support and protection. Contained within the cells are several soluble compounds, most of which are not readily digestible. Since cell wall material is the primary constituent of plants, one of the main objectives of forage analysis is to characterize the cell wall fibre. Plant fibre has three major components viz., cellulose, hemi cellulose, and lignin. Cellulose and hemi cellulose are digestible to some extent by ruminants. Ruminants can convert these fibre components to energy because the rumen provides the correct environment for bacteria and other microorganisms that actually break down the fibre but lignin is indigestible, and thus cannot be used by ruminants for energy. Crude fibre increases with increase in age, so it could be ascribe to the accumulation of structural material such as hemi cellulose, cellulose, lignin, silica etc. These results are supported with the findings of Ranjhan (1980).

Table.1 Effect of intercropping on Green Fodder and Dry Fodder Yield, Sorghum equivalent yield $\left(\mathrm{q} \mathrm{ha}^{-1}\right)$ and LER at harvest

\begin{tabular}{|c|c|c|c|c|}
\hline Treatments & $\begin{array}{l}\text { Total Green } \\
\text { fodder yield } \\
\left(\mathrm{q} \mathrm{ha} \mathbf{a}^{-1}\right)\end{array}$ & $\begin{array}{c}\text { Total Dry } \\
\text { fodder yield } \\
(\mathbf{q ~ h a - 1 )}\end{array}$ & $\begin{array}{c}\text { Sorghum } \\
\text { Equivalent } \\
\text { Yield }\left(\mathbf{q ~ h a} \mathbf{~ h}^{-1}\right)\end{array}$ & LER \\
\hline Sorghum (sole) & 460.83 & 100.81 & 460.83 & 1.00 \\
\hline $\begin{array}{l}\text { Pearl millet } \\
\text { (sole) }\end{array}$ & 366.74 & 80.76 & 366.74 & 1.00 \\
\hline Cowpea (sole) & 247.67 & 54.66 & 330.22 & 1.00 \\
\hline$S+C(1: 1)$ & 455.41 & 98.67 & 509.34 & 1.29 \\
\hline$S+C(1: 2)$ & 393.71 & 86.39 & 464.98 & 1.26 \\
\hline$S+C(2: 1)$ & 490.99 & 103.30 & 531.54 & 1.30 \\
\hline$S+C(2: 2)$ & 451.05 & 96.32 & 503.92 & 1.28 \\
\hline$P+C(1: 1)$ & 388.61 & 83.70 & 441.37 & 1.27 \\
\hline$P+C(1: 2)$ & 358.12 & 78.67 & 429.04 & 1.26 \\
\hline$P+C(2: 1)$ & 410.17 & 84.21 & 450.64 & 1.28 \\
\hline$P+C(2: 2)$ & 386.61 & 83.73 & 439.95 & 1.27 \\
\hline SEm \pm & 11.88 & 1.97 & 12.86 & 0.03 \\
\hline $\mathrm{CD}(\mathrm{P}=\mathbf{0 . 0 5})$ & 35.06 & 5.80 & 37.95 & 0.10 \\
\hline
\end{tabular}

$\mathrm{S}=$ Sorghum, $\mathrm{P}=$ Pearl millet, $\mathrm{C}=$ Cowpea, $\mathrm{LER}=$ Lend equivalent ratio 
Table.2 Effect of intercropping on weighted average crude protein, crude fiber and ash content (\%) of fodder sorghum, pearl millet and cowpea at harvest

\begin{tabular}{|c|c|c|c|c|c|c|c|c|c|c|c|c|}
\hline \multirow[t]{2}{*}{ Treatments } & \multicolumn{4}{|c|}{ Crude protein (\%) } & \multicolumn{4}{|c|}{ Crude fiber (\%) } & \multicolumn{4}{|c|}{ Ash content (\%) } \\
\hline & $\begin{array}{c}\text { Sorghu } \\
\text { m }\end{array}$ & $\begin{array}{l}\text { Pearl } \\
\text { millet }\end{array}$ & Cowpea & $\begin{array}{c}\text { WACP } \\
(\%)\end{array}$ & Sorghum & $\begin{array}{l}\text { Pearl } \\
\text { millet }\end{array}$ & Cowpea & $\begin{array}{c}\text { WACF } \\
(\%)\end{array}$ & $\begin{array}{l}\text { Sorghu } \\
\text { m }\end{array}$ & $\begin{array}{l}\text { Pearl } \\
\text { millet }\end{array}$ & $\begin{array}{c}\text { Cowpe } \\
\text { a }\end{array}$ & $\begin{array}{c}\text { WAAC } \\
(\%)\end{array}$ \\
\hline Sorghum (sole) & 7.51 & -- & -- & 7.51 & 29.21 & - & - & 29.21 & 10.35 & - & - & 10.35 \\
\hline $\begin{array}{l}\text { Pearl millet } \\
\text { (sole) }\end{array}$ & -- & 7.29 & -- & 7.29 & - & 29.11 & - & 29.11 & - & 10.44 & - & 10.44 \\
\hline Cowpea (sole) & -- & -- & 18.16 & 18.16 & - & - & 23.42 & 23.42 & - & - & 15.89 & 15.89 \\
\hline$S+C(1: 1)$ & 8.48 & -- & 16.62 & 10.80 & 27.41 & - & 24.75 & 26.66 & 10.66 & - & 15.50 & 12.04 \\
\hline$S+C(1: 2)$ & 8.65 & -- & 17.02 & 12.37 & 26.87 & - & 24.26 & 25.72 & 10.93 & - & 15.75 & 13.04 \\
\hline$S+C(2: 1)$ & 7.98 & -- & 15.34 & 8.85 & 28.40 & - & 25.00 & 27.83 & 10.41 & - & 15.11 & 11.11 \\
\hline$S+C(2: 2)$ & 8.47 & -- & 15.87 & 10.57 & 27.05 & - & 24.83 & 26.42 & 10.74 & - & 15.58 & 12.11 \\
\hline$P+C(1: 1)$ & -- & 8.51 & 15.68 & 10.74 & - & 27.66 & 24.32 & 26.62 & - & 10.64 & 15.37 & 12.14 \\
\hline$P+C(1: 2)$ & -- & 8.73 & 17.03 & 12.61 & - & 27.23 & 24.19 & 25.79 & - & 10.96 & 15.68 & 13.19 \\
\hline$P+C(2: 1)$ & -- & 7.68 & 15.21 & 8.61 & - & 28.11 & 24.86 & 27.64 & - & 10.45 & 15.09 & 11.21 \\
\hline$P+C(2: 2)$ & -- & 8.54 & 16.81 & 11.11 & - & 27.59 & 24.28 & 26.56 & - & 10.69 & 15.48 & 12.16 \\
\hline SEm \pm & -- & -- & -- & 0.30 & -- & -- & -- & 0.28 & -- & -- & -- & 0.13 \\
\hline $\mathrm{CD}(\mathrm{P}=\mathbf{0 . 0 5})$ & -- & -- & -- & 0.90 & -- & -- & -- & 0.83 & -- & -- & -- & 0.39 \\
\hline
\end{tabular}

$\mathrm{S}=$ Sorghum, $\mathrm{P}=$ Pearl millet, $\mathrm{C}=$ Cowpea, $\mathrm{WACP}=$ Weighted average crude protein, $\mathrm{WACF}=$ Weighted average crude fiber and WAAC $=$ Weighted average ash content 
Table.3 Effect of intercropping on total crude protein yield ( $\mathrm{q} \mathrm{ha}^{-1}$ ) of fodder sorghum, pearl millet and cowpea at harvest

\begin{tabular}{|l|c|c|c|c|}
\hline \multirow{2}{*}{ Treatment } & \multicolumn{2}{|c|}{ Crude protein yield $\left(\mathbf{q} \mathbf{h a}^{-\mathbf{1}}\right)$} & \multirow{2}{*}{$\begin{array}{c}\text { Total crude protein } \\
\text { yield }\left(\mathbf{q} \mathbf{~ h a}^{\mathbf{- 1}}\right)\end{array}$} \\
\cline { 2 - 5 } & Sorghum & Pearl millet & Cowpea & 5.12 \\
\hline Sorghum (sole) & 5.12 & - & - & 4.69 \\
\hline $\begin{array}{l}\text { Pearl millet } \\
\text { (sole) }\end{array}$ & - & 4.69 & - & 4.80 \\
\hline Cowpea (sole) & - & - & 4.80 & 5.24 \\
\hline S + C (1:1) & 2.94 & - & 2.30 & 5.10 \\
\hline S + C (1:2) & 2.02 & - & 3.08 & 5.52 \\
\hline S + C (2:1) & 4.02 & - & 1.50 & 5.21 \\
\hline S + C (2:2) & 2.93 & - & 2.28 & 4.89 \\
\hline P + C (1:1) & - & 2.6 & 2.29 & 4.82 \\
\hline P + C (1:2) & - & 1.75 & 3.07 & 5.11 \\
\hline P + C (2:1) & - & 3.60 & 1.51 & 4.86 \\
\hline P + C (2:2) & - & 2.58 & 2.28 & $\mathbf{0 . 0 9}$ \\
\hline SEm \pm & -- & -- & -- & $\mathbf{0 . 2 7}$ \\
\hline CD (P=0.05) & -- & -- & -- & \\
\hline
\end{tabular}

$\mathrm{S}=$ Sorghum, $\mathrm{P}=$ Pearl millet, $\mathrm{C}=$ Cowpea

Table.4 Effect of intercropping on gross returns, net return (Rs. ha ${ }^{-1}$ ), B: C ratio and Net profitability (Rs. ha ${ }^{-1}$ day $^{-1}$ )

\begin{tabular}{|c|c|c|c|c|c|}
\hline Treatments & $\begin{array}{c}\text { Cost of } \\
\text { cultivation } \\
\left(\mathbf{R s} . \mathbf{h a}^{-1}\right)\end{array}$ & $\begin{array}{c}\text { Gross } \\
\text { returns } \\
\left(\text { Rs. ha }{ }^{-1}\right)\end{array}$ & $\begin{array}{l}\text { Net returns } \\
\left(\text { Rs. ha }{ }^{-1}\right)\end{array}$ & B:C Ratio & $\begin{array}{c}\text { Net } \\
\text { profitability } \\
\left(\text { Rs. ha } \text { hay }^{-1}\right)\end{array}$ \\
\hline Sorghum (sole) & 23814 & 69125 & 45311 & 1.90 & 742.80 \\
\hline $\begin{array}{l}\text { Pearl millet } \\
\text { (sole) }\end{array}$ & 22942 & 55011 & 32069 & 1.40 & 525.71 \\
\hline Cowpea (sole) & 24775 & 49533 & 24758 & 1.00 & 405.87 \\
\hline$S+C(1: 1)$ & 24295 & 76401 & 52106 & 2.14 & 854.20 \\
\hline$S+C(1: 2)$ & 24455 & 69748 & 45293 & 1.85 & 742.51 \\
\hline$S+C(2: 1)$ & 24134 & 79731 & 55597 & 2.30 & 911.42 \\
\hline$S+C(2: 2)$ & 24295 & 75588 & 51293 & 2.11 & 840.87 \\
\hline$P+C(1: 1)$ & 23859 & 66205 & 42347 & 1.77 & 694.21 \\
\hline$P+C(1: 2)$ & 24164 & 64357 & 40193 & 1.66 & 658.90 \\
\hline$P+C(2: 1)$ & 23553 & 67596 & 44043 & 1.87 & 722.01 \\
\hline$P+C(2: 2)$ & 23859 & 65992 & 42134 & 1.77 & 690.71 \\
\hline SEm \pm & - & 1930 & 1930 & 0.08 & 31.63 \\
\hline $\mathrm{CD}(\mathrm{P}=\mathbf{0 . 0 5})$ & - & 5692 & 5692 & 0.24 & 93.31 \\
\hline
\end{tabular}

$\mathrm{S}=$ Sorghum, $\mathrm{P}=$ Pearl millet, $\mathrm{C}=$ Cowpea 


\section{Ash content}

Data pertaining to weighted average ash content of sorghum, pearl millet and cowpea are furnished in table 2. Ash content was found significantly higher in sole cowpea $(15.89 \%)$ than other treatments. This was followed by the ash content under pearl millet + cowpea with 1:2 row ratio $(13.19 \%)$ and sorghum + cowpea with 1:2 row ratio (13.04 $\%)$ which were statistically at par with each other but significantly greater than other treatments except sole cowpea. While ash content decreases with the maturity could results from dilution of minerals as crop matures. This finding was also supported with Dahmardeh et al., (2010).

\section{Crude protein yield}

The data on crude protein yield of sorghum, pearl millet and cowpea are individually presented in table 3 . The highest dry matter yield of sorghum could be the reason for higher crude protein yield. In intercropping of fodder sorghum + cowpea (2:1) resulted the highest crude protein yield $\left(5.52 \mathrm{q} \mathrm{ha}^{-1}\right)$ due to highest crude protein content in the legume component and higher total dry matter yield of fodder sorghum at the time of harvest. Raman Kumar and Bhanumurthy (2001), Kumar and Prasad (2003), Kumar et al., (2005) and Sharma et al., (2008) also reported that the higher crude protein yield.

\section{Gross returns net returns and B: $\mathrm{C}$ ratio}

The data pertaining to gross returns and net returns of sorghum, pearl millet and cowpea intercropping are presented in table 4 . The data indicated that gross return was significantly influenced by different treatments of intercropping in the experiment. The significantly maximum gross return was recorded from sorghum and cowpea intercropping with 2:1 row ratio (Rs. 79,731) which was statistically comparable with that of sorghum and cowpea intercropping (1:1) row ratio with a gross return of Rs.76, 401. The maximum net return (Rs. ha ${ }^{-1}$ ) was also obtained from 2:1 row ratio intercropping of sorghum and cowpea (Rs. 55597) which was significantly superior over all the row ratios of intercropping system. The benefit cost ratio was found significantly higher (2.30) in sorghum and cowpea $2: 1$ row ratio intercropping of followed by $1: 1$ row ratio of sorghum and cowpea intercropping. Similar result was found by Bhagat Sapna et al., (2017).

On the basis of these findings, it is concluded that, Intercropping of forage sorghum with cowpea 2:1 row ratio gave higher crude protein yield and green fodder yield having maximum net returns, LER and $\mathrm{B}$ : $\mathrm{C}$ ratio. Hence, it is for higher productivity and higher economic returns, the intercropping of sorghum and cowpea with 2:1 row ratio can be adopted in medium to up land situations for farmers with quality green fodder and higher net returns.

\section{References}

Abbas M (2005) Studies on growth, yield and quality of sorghum fodder sown alone and with legumes in different geometrical patterns M.Sc. (Hons.) Thesis, Deptt. of Agronomy Univ. Agri., Faisalabad.

Abd El-Shafy AS, Tarrad MM, Fahmy AH (2009) Effect of intercropping patterns of teosinte with cowpea on yield, quality and their competitive relationships. Ann of Agric. Sci., Moshtohor, 47(3): 215-224.

Acikgoz E, Sincik M, Karasu A, Tongel O, Wietgrefe G, Bilgili U, Albayrak S, Turan Z, Goksoy A. (2008). Forage soybean production for seed in Mediterranean environments. Field Crops Research 110, 213-218.

Amedie B, Hiremath SM, Chittapur BM, 
Halikatti SL, Chimmad VP (2004) Intercropping of grain legumes in sorghum. Karnataka Journal of Agricultural Sciences, 17(1): 22-27.

Bhagat Sapna, Gupta M, Banotra M, Sharma A, Kumar S, Sharma A (2017) production potential and economics of fodder maize (Zea mays) varieties sown under varying intercropping systems with cowpea (Vigna unguiculata). Int. J. Curr. Microbiol. App. Sci., 6(12): 40824087.

Crew TE, Peoples MB (2004) Legume versus fertilizer source of nitrogen: Ecological tradeoffs and human needs. Agric. Ecol. Eviron. 102: 279-297.

Dahmardeh M, Ghanbari A, Syasar B. Ramroudi M. (2010) Effect of inter cropping maize (Zea mays L.) with cowpea (Vigna unguiculata) on green forage yield and quality evaluation. Asian Journal of Plant Sciences.8 (3): 235-239.

Eskandari and Ghanbari (2009) Intercropping of maize and cowpea as whole crop forage: effect of different planting pattern on total dry matter production and maize forage quality. Notulae Botanicae Horti Agrobotanici ClujNapoca. 37(2): 152-155.

Gare BN, More SM, Burli AV, Dodake SS (2009) Evaluation of yield stability in soybean based intercropping system under rainfed agriculture. Indian Journal of Dry land Agriculture Research and Development, 24, 84-87.

Ghosh PK, Mannab MC, Bandyopadhyay KK, Ajay TK, Wanjari RH, Hati KM, Misra AK, Acharyab CL, Rao AS (2006) Inter specific interaction and nutrient use in soybean/ sorghum intercropping system. Agronomy Journal 98, 1097-1108.

Girase PP, Pralhad, Sonawane D, Sanjivkumar, Wadile C (2007) Effect of pearl millet (Pennisetum glaucum) based intercropping system on yield and economics of pearl millet on shallow soils under rainfed conditions. International J. Agric. Sci. Vol.3 No. 2: 192-193

Ibrar R, Shahbaz A, Malik MA (2002) Sunflower-summer legumes intercropping systems under rainfed conditions: Yield and yield components. Pak. J. Agric. Res., 17: 231-236.

Iqbal A, Ayub M, Zaman H, Ahmad R (2006) Impact of nutrient management and legume association on forage qualitative traits of maize forage. Pakistan Journal of Botany, 38, 1079-1084.

Iqbal MA, Iqbal AA, Raza AZ, Faizal N. (2015) Over viewing forage maize yield and quality attributes enhancement with plant nutrition management. World Journal of Agricultural Sciences. 11(3):128-134.

Iqbal, MA (2018). Comparative performance of forage cluster bean accessions as companion crops with sorghum under varied harvesting times. Bragantia, 77(3): 476-484.

Javanmard A, Mohammadi- Nasab AD, Javanshir A, Moghaddam M, Janmohammadi H (2009) Forage yield and quality in intercropping of maize with different legumes as doublecropped. J. Food Agric Enviro. 7(1): 163-166.

Kumar P, Prasad NK (2003) Biological and economical sustainability of forage maize (Zea mays) + cowpea (Vigna unguiculata) intercrop. Indian Journal of AgriculturalSciences.73 (6): 341342.

Li L, Zhang FS, Li XL, Christie P, Sun JH, Yang SC, Tang C (2003) Inter specific facilitation of nutrient uptake by intercropped maize and faba bean. Nutr. Cycling Agro. Eco., 68: 61-71.

Mpairwe DR, Sabiiti EN, Ummuna NN, Tegegne A and Osuji P (2002) Effect of 
intercropping cereal crops with forage legumes and sources of nutrients on cereal grain yield and fodder dry matter yields. African Crop Sci. J., 10(1): 8197

Oseni T, Olusegun (2010) Evaluation of Sorghum-Cowpea Intercrop Productivity in Savanna Agro-ecology using Competition Indices. Journal of Agricultural Science Vol. 2, No. 3.

Pal MS, Reza A, Joshi YP, Panwar UBS (2014) Production potential of forage sorghum (Sorghum bicolor L.) under different intercropping systems. Agriculture for Sustainable Development 2(2):87-91.

Papastylianou I (2004) Effect of rotation system and $\mathrm{N}$ fertilizer on barley and common vetch grown in various crop combinations and cycle lengths. J. Agric. Sci. 142, 41-48.

Ramanakumar K, Bhanumurthy VB (2001)
Effect of staggered sowing and relative proportion of cowpea on the performance of maize + cowpea. Forage Research. 27 (2):105-110.

Rao SH, Mayeux, Northup B (2005) Performance of forage soybean in Southern great plains. Crop Science. 45, 1973-1977.

Sharma RP, Singh AK, Poddar BK, Raman KR (2008) Forage production potential and economics of maize (Zea mays L.) with legumes intercropping under various row proportions. Indian Journal of Agronomy 52(2): 121-124.

Sheaffer C, Orf J, Devine T, Jewett J (2001) Yield and quality of forage soybean. Agronomy Journal. 93, 99-106

Singh SP (1983) Studies on spatial arrangement in sorghum legume intercropping system. Journal of Agricultural Science., Cambridge. 97: 655-661.

\section{How to cite this article:}

Ramanand Chaudhary, Sanjeev Kumar Gupta, Anshuman Kohli, Suborna Roy Choudhury and Singh, M. K. 2020. Studies on Green Fodder Yield, Quality and Economics of Cereal Forage Sown alone and Intercrop with Cowpea. Int.J.Curr.Microbiol.App.Sci. 9(11): 1893-1902. doi: https://doi.org/10.20546/ijcmas.2020.911.224 